\title{
Dampak Game online terhadap Perilaku Siswa di Lingkungan SMA Negeri 1 Bayang
}

\author{
Nurul Ismi, Akmal \\ Program Studi Pendidikan Pancasila dan Kewarganegaraan \\ Universitas Negeri Padang \\ E-mail: Nurulismi912@gmail.com
}

\begin{abstract}
ABSTRAK
Penelitian ini di latar belakangi oleh game online yang membuat siswa ketagihan dalam bermain game online, motivasi belajar siswa menurun, dan siswa menjadi kurang disiplin terhadap waktu, serta siswa tidak mempedulikan lingkungan disekitar mereka hanya mempedulikan teman yang ada didunia maya game online. Metode penelitian digunakan adalah penelitian kualitatif dan metode deskriptif. Informannya adalah kepala sekolah, guru PPKn, guru kelas, siswa SMA Negeri 1 Bayang, orang tua siswa, dan masyarakat sekitar. Data dikumpulkan melalui observasi, wawancara, dan dokumentasi. Setelah data diperoleh, data di analisis menggunakan teori Miles dan Huberman. Hasil penelitian menunjukan bahwa dampak game online terhadap perilaku siswa dilingkungan SMA Negeri 1 Bayang berdampak positif yaitu siswa memiliki banyak teman dan dampak negatifnya yaitu motivasi belajar siswa menurun. Sehingga upaya yang dilakukan yaitu melalui bimbingan orang tua dan guru dengan memberikan nasehat kepada anak, melakukan razia handphone oleh guru dan memeriksa sosial media yang digunakan bekerjasama dengan orang tua siswa.
\end{abstract}

Kata Kunci: game online, perilaku siswa, lingkungan SMA

\section{ABSTRACT}

This research is motivated by online games that make students addicted to playing online games, students' motivation to learn decreases due to addiction to playing online games, students become less disciplined about time, and students do not care about the environment around them only care about friends in cyberspace online gaming. The research method used is qualitative research and descriptive methods. The informants were school principals, teacher teachers, class teachers, high school students in the Bayang State, parents of students, and the surrounding community. Data collected through observation, interviews, and documentation. After the data obtained the data is analyzed using theory Miles and Huberman. The results showed that the impact of online games on student behavior in the State of the High School One Bayang had a positive impact on students having a lot of friends and negative namely student motivation to decrease. So the efforts made are through the guidance of the parents and teachers by giving advice to children, conducting mobile raid by the teacher and checking the social media used cooperates with the parents of students. 
Keywords : online games, student behavior, high school environment

This work is licensed under the Creative Commons Attribution-ShareAlike 4.0 International License. (2019 by author.

\section{PENDAHULUAN}

Kemajuan teknologi informasi dan komunikasi yang sangat pesat saat sekarang ini telah banyak digunakan orang. Salah satu dampak dari kemajuan teknologi yaitu internet. Berbagai informasi dapat di akses melalui internet secara bebas. Tidak hanya informasi, berbagai saran hiburan juga dapat diproses antara lain game online. Bermain game online secara berlebihan tentu membawa dampak yang negatif atau positif. Hal ini akan berdampak pada pada perilaku siswa yang mengarah kepada perilaku penyimpangan sosial. Banyaknya waktu yang dihabiskan hanya untuk bermain game online akan berpengarauh terhadap perilaku siswa antara lain malas belajar, bolos sekolah dan sering telat datang ke sekolah. Penyimpangan yang telah dilakukan siswa akibat dari bermain game online yaitu berlaku tidak jujur. Kebiasaan tidak jujur ini dilakukan siswa karena masih meminta uang jajan ke orang tua, sehingga jika siswa tidak jujur untuk mengatakan dengaan secara lansung kepada orang tua untuk bermain game online, tentu orang tua akan sulit untuk memberikannya. Dengan alasan berbohong seperti itulah untuk siswa dapat bermain game online.

Penelitian oleh Fauziah (2013) menyatakan bahwa mengakses game online membuat siswa SMP N 1 Samboja cenderung berperilaku positif dan negatif. Perilaku positifnya yaitu siswa dapat memiliki banyak teman sehingga siswa dapat berkomunikasi dan berinteraksi serta bertukaran pikiran sehingga wawasan siswa bertambah. Kemudian siswa SMP N 1 Samboja cenderung berperilaku negatif yaitu siswa menjadi malas belajar seperti menunda mengerjakan tugas sekolah dan mengakses game online ketika jam pelajaran. Dalam penelitian Anggraini, hubungan ketergantungan media pada remaja yaitu remaja menjadi ketergantungan pada game online. ketergantungan tercipta karena dengan sendirinya dan tanpa disadari oleh remaja telah bergantung pada game online. Semakin besar ketergantungan seseorang terhadap media, maka semakin besar pula efek yang dapat ditimbulkan media terhadap orang bersangkutan. Menurut Cambrige Dictionary dalam jurnal (Andrew,2017:181) kecanduan adalah menyukai dan memiliki sesuatu dengan secara berlebihan sehingga melupakan hal lain. Oleh karena itu game online memberikan hiburan bagi siswa dan tantangan untuk memainkannya sehingga menjadi salah satu hal yang sangat di sukai oleh siswa dalam memainkan game online. Dalam jurnal Andrew (2017:182) menyatakan bahwa kecanduan game online merupakan memainkan game online dengan secara berlebihan sehingga menjadikan game online sebagai fokus utama dan mendapatkan perhatian yang baik dari yang lain tanpa memikirkan hal lain yang akan di kerjakan. 
Perubahan perilaku siswa yang mengalami kecanduan game online mungkin tidak rasakan, namun dapat dirasakan oleh orang disekitar lingkungan mereka terutama pada orang tua. Pada dasarnya perilaku manusia dibentuk oleh lingkungan sosialnya. Menurut Kartono (2005:6), perilaku merupakan segala aktivitas, perbuatan, serta penampilan diri seseorang yang dilakukan dalam kehidupan sehari-hari.

Menurut Skiner dikutip oleh Notoatmodjo bahwa perilaku reaksi seseorang terhadap rangsangan dari luar yang dialaminya. Melalui lingkungan sosial maka akan timbul perilaku yang berbeda-beda. Perilaku yang terjadi karena adanya rangsangan dari luar yang dapat mempengaruhi. Teori perilaku menurut Eka Rusnani Fauziah (2013:5) sebagai berikut : 1) teori insting, perilaku yang telah ada dalam diri seseorang dari bawaan gen atau dari lahir 2) teori dorongan, dorongan yang terjadi dalam diri dan lingkungan sekitar yang berkaitan dengan mencapai kebutuhan seseorang 3) teori isentif, perilaku seseorang yang memperhitungkan baik dan buruk yang akan terjadi sebelum mengambil keputusan 4) teori atribusi, seseorang yang memilih hal yang mesti dilakukan seseorang yang memikirkan hal apa yang aka terjadi pada diri seseorang dalam bertindak. Dengan siswa melakukan interaksi satu sama lain maka akan ada perilaku positif dan perilaku negatif yaitu siswa yang patuh dengan peraturan tata tertib sekolah merupakan perilaku positif, siswa yang sering melanggar peraturan tata tertib sekolah merupakan peraturan negatif.
Menurut UU No.20 Tahun 2003 siswa adalah anggota keluarga masyarakat yang berusaha mengembangkan potensi diri melalui proses pembelajaran yang tersedia pada jalur jenjang dan jenis pendidikan tertentu. Siswa merupakan mereka yang dengan sengaja datang ke sekolah untuk menuntut ilmu disekolah dengan melatih kemampuan yang dimiliki untuk meraih citacitanya. Menurut Sadulloh (2015:135) siswa adalah seseorang yang memiliki potensi dan sedang berkembang dengan bantuan pendidik untuk mengembangkan kemampuan yang dimiliki secara optimal.

\section{METODE PENELITIAN}

Metode penelitian yang digunakan dalam penelitian ini deskriptif kualitatif. Disebut dengan penelitian deskriptif karena penelitian ini berusaha membuat deskripsi, gambaran dan lukisan tentang sesuatu keadaan atau peristiwa sebagaimana adanya. Berdasarkan tujuan penelitian, permasalahan yang akan dikaji pada penelitian ini bersifat sosial dan dinamis. Lokasi penelitian ini diambil berdasarkan observasi awal yang dilakukan peneliti melihat bahwasanya siswa SMA Negeri 1 Bayang banyak yang menggunakan game online. Hal ini tentu menjadi pertanyaan bagaimana cara pihak keluarga terutama orang tua, pihak sekolah mendidik dan memahami anak dan siswa tersebut. Oleh karena itu lokasi tersebut menjadi objek penelitian peneliti.

Informan dalam penelitian ini dipilih dengan metode purposive sampling, yaitu pemilihan informan berdasarkan kriteria orang yang mengetahui atau yang bisa 
dimanfaatkan untuk memberikan informasi tentang situasi dan kondisi objek penelitian serta yang mempunyai banyak pengalaman tentang latar belakang penelitian. Informan yang terlibat dalam penelitian ini ialah sebanyak 15 orang informan, 1 orang kepala sekolah, 1 guru PPKN, 1 guru kelas, 10 orang siswa-siswi serta 2 orang tua siswa SMA Negeri 1 Bayang. Penelitian dilakukan melalui observasi, wawancara, dokumentasi, dan studi kepustakaan. Dalam mengumpulkan data penelitian menggunakan pedoman wawancara, dibantu dengan alat perekam, kamera dan buku catatan. Untuk menguji keabsahan data penelitian, peneliti menggunakan teknik triangulasi, yaitu pengecekan data melalui berbagai teknik, sumber, dan metode yang digunakan.

\section{HASIL DAN PEMBAHASAN}

Faktor Yang Melatarbelakangi Siswa Bermain Game online

Faktor yang melatar belakangi siswa SMA Negeri 1 Bayang kecanduan bermain game online ada tiga diantaranya pertama faktor dalam diri dimana siswa merasa bosan atau kejenuhan akan rutinitas sehariharinya seperti banyak tugas-tugas dari sekolah. Kemudian stress terhadap masalah yang dapat meganggu pola fikir. Maka siswa melampiaskan bermain game online tanpa memikirkan banyak waktu yang telah di lewatkan untuk membuat dirinya senang. Kedua, faktor berasal dari luar diri siswa. Kurangnya komunikasi orang tua dan anggota keluarga lainnya terhadap anak sehingga bimbingan dari orang tua berkurang. Anak tidak bisa berkeluh kesah bersama anggota keluarganya.
Hal ini akan menimbulkan dampak negatif terhadap mereka karena jiwanya merasa kosong sehingga mereka mencari kegiatan lain yaitu bermain game online yang dapat mengisi kekosongan yang ada dalam dirinya serta juga bisa berkomunikasi lansung bersama lawan game. Ketiga, Banyaknya teman sebaya dan masyarakat sekitar yang bermain game online. Hal ini cenderung dapat berpengaruh pada siswa dengan ajakan dari teman untuk bermain game online.

Kondisi ini sesuai dengan penelitian terdahulu yang menyatakan faktor internal yang dapat menyebabkan adiksi mengenai game online yaitu adanya rasa jenuh siswa saat berada di rumah dan sekolah (Hardiyansyah: 2016 ). Sesuai dengan artikel yang menyatakan bahwa kontrol diri rendah saat bermain game online hingga kecanduan, karena kehidupan anak diperlukan moral dan agama yang dapat diperhatikan (metrotvnews, 2019). Pada orang tua yang terpisah dengan anak-anaknya memiliki hambatan untuk komunikasi karena berjarak dengan secara fisik. Sehingga pada keluarga yang modern muncullah gadget canggih yang menyebabkan komunikasi kurang dengan anggota keluarga lainnya. Ketergantungan pada gadget membuat keluarga menjalani kesibukan masing-masing bahkan berada dalam satu ruangan mereka tidak saling berkomunikasi.

Penelitian terdahulu dari Agustina (2016:293) menyatakan bahwa game online adalah game yang terhubung melalui konektivitas internet atau Local Area Network sehinngga permainan dapat tersambung dengan para pemain yang 
lainnya dengan permainan yang sama. Penelitian oleh Giandi (2012) menyatakan bahwa melalui interaksi komunikasi mereka lakukan, pemain banyak memiliki teman baru selama bermain game online bahkan pertemanan tersebut berlansung dapat kedunia nyata. Mereka yang berada dalam satu kabupaten/kota dapat bertemu dengan secara lansung. Namun bila tidak berada dalam satu kabupaten/kota mereka melakukan pertemuan secara khusus.

Dampak game online Terhadap siswa

Dampak positif dari game online untuk pelajar diantaranya:

Dapat meluapkan emosionalnya melalui bermain game online. Mereka mengajak teman yang membuat mereka kesal untuk bertanding dalam permainan, sehingga dalam bermain game online tersebut dilampiaskan kekesalan yang dirasakannya. Pengakuan dari salah seorang siswa SMA Negeri 1 Bayang bernama Andes mengatakan dia tidak menyukai perkelahian fisik. Sehingga untuk menghilangkan kekesalan yang di rasakan dengan bertanding bersama teman yang membuat dia kesal di area game.

Siswa memanfaatkan game online sebagai peluang bisnis untuk mendapatkan penghasilan tambahan. Siswa bermain game online membutuhkan paket internet oleh karena itu. Mereka memperjual belikan akun game online tersebut untuk mendapatkan uang tambahan dan membeli paket internet tanpa meminta kepada orang tua.
Dampak negatif game online untuk pelajar diantaranya :

Siswa mencuri waktu untuk bermain game online disaat jadwal waktu belajar. Sehingga siswa kurang mengontrol diri dengan mengabaikan kewajiban untuk belajar disekolah akibat kecanduan bermain game online. Rakes siswa SMA Negeri 1 Bayang mengatakan merasa bosan di dalam kelas melihat guru tidak menerangkan pelajaran hanya diminta mencatat, sehingga dia bermain game online dengan mengambil posisi tempat duduk dibelakang agar tidak kelihatan oleh guru.

Siswa tidur dalam kelas, telat datang ke sekolah bahkan memilih bolos. Hal ini terjadi karena siswa bermain game online hingga larut malam sehingga sering tertidur dalam kelas telat dan bolos untuk sekolah. Siswa memilih bermain game online pada malam hari dengan alasan jaringan internet yang kuat. Akibatnya siswa ketiduran dan melupakan kewajiban mereka untuk kesekolah.

Siswa tidak mempedulikan kegiatan lainnya yaitu melalaikan shalat dan telat makan. Karena kurangnya kontrol dalam diri siswa tersebut. Siswa kecanduan bermain game online telah membuat resah orang tua dan guru karena banyak terpengaruh. Hal ini terjadi dalam bermain game online dapat berkomunikasi lansung dengan teman dekat, pacar ataupun saudara Karena keasyikan bermain sambil bercerita sehingga waktu shalat dan makan terlupakan.

Siswa menggunakan uang jajan dan uang sekolah untuk bermain game online. Bermain game online membutuh 
jaringan koneksi internet sehingga siswa menghabiskan paket internet sebulan kurang dan lebihnya sebanyak Rp 50.000 rupiah. Jefri siswa SMA Negeri 1 Bayang memanfaatkan uang jajan sekolah tersebut untuk dapat membeli paket internet kembali dengan cara tidak menghabiskan uang tersebut disekolah dan tidak makan pada jam istirahat. Namun dia mengumpulkan uang tersebut untuk dapat membeli paket internet.

Berbahasa yang tidak sopan dan santun. Mereka menggunakan bahasa yang tidak sopan terhadap teman seperti menghina dan menjelekkan teman. Ini juga dampak dari teman yang kebiasaannya suka berkata kasar. Apabila mengalami kekalahan dalam bermain game online kebiasaan mereka berkata kasar dan tidak sopan telah menjadi hal biasa. Sehingga ucapan tersebut dengan mudahnya mereka dilontarkan pada saat bermain game online.

\section{Menurut}

(2016:154) dampak teknologi yaitu jaringan internet. perkembangan berkembanglah teknologi salah satunya adalah game online. Menurut Agustinus Nilwan menyatakan game merupakan permainan komputer yang dibuat menggunakan animasi dan juga memahami teknik dan motode animasi sebab semuanya akan saling bekaitan. Game online membawa banyak dampak bagi kehidupan masyarakat, semua itu bisa tergantung kepada penggunaannya. Beberapa dampak akibat tingginya intensitas bermain game online yaitu tidak memiliki prioritas dalam menjalani aktivitas sehari-hari serta menyebabkan malas belajar.
Upaya Guru dalam Menanggulangi Perilaku Siswa Akibat Kecanduan Game online

Upaya guru untuk menangani perilaku siswa kecanduan bermain game online sebagai berikut :

Memberikan Nasehat. Jika kedapatan perubahan perilaku negatif yang dialami siswa karena keseringan bermain game online sehingga siswa itu sering tidur dalam PBM, maka yang bersangkutan dipanggil ke kantor untuk diberikan nasehat langsung kepadanya mengenai dampak game online terhadap perilaku siswa. Siswa juga diberikan motivasi bahwa kecanduan game online dapat merusak pola fikir agar siswa dapat menyadarinya dengan baik.

Melaksanakan Razia. Peraturan tata tertib sekolah SMA Negeri 1 Bayang bahwa siswa dilarang membawa handphone,Ipad, Tablet ke sekolah. Bila kedapatan siwa tetap membawa hand phone,Ipad, tablet dan menggunakan pada PBM berlansung maka guru langsung menyita telepon genggam siswa dan diberikan sanksi lansung di sekolah.

Hal ini dilakukan guru agar siswa jera untuk tidak menggunakan handphone pada saat PBM (proses belajar mengajar) berlangsung. Upaya menyita handphone, ipad, tablet yang dilakukan guru ini sebelumya telah dimusyawarahkan sebelum sekolah dimulai dengan orang tua siswa pada saat rapat perkumpulan semua orang tua siswa. Tujuan penyitaan handphone pada siswa untuk menegakan disiplin, mencegah timbulnya hal negatif, serta meningkatkan kosentrasi siswa dalam belajar. 
Kerjasama dengan orang tua siswa. Kepala sekolah SMA Negeri 1 Bayang membentuk peraturan tata tertib sekolah yang kerjasama bersama orang tua siswa yang disampaikan pada saat perkumpulan rapat orang tua sebelum aktivitas sekolah akan dimulai untuk memutuskan peraturan tata tertib. Hal ini di lakukan agar motivasi yang diberikan sekolah dan orang tua dirumah sama terhadap anak. Selain itu harapannya orang tua siswa dapat menerima anaknya diberikan sanksi terhadap perbuatan yang melangar peraturan yang telah di sepakati oleh sekolah bersama orang tua.

Dalam Undang-Undang No. 14 tahun 2005 tentang guru dan dosen, disebutkan bahwa guru adalah pendidik professional dengan mendapat tugas utama mengajar, mendidik, membimbing, melatih, mengarahkan, menilai dan mengevaluasi peserta didik pada pendidik anak usia dini, pendidikan formal, pendidikan dasar, dan pendidikan menengah. Hubungan guru dan siswa seperti halnya seorang petani dengan tanamannya. Seorang petani tidak bisa memaksa agar tanamannya cepat berbuah dengan menarik batang atau daunnya.Tanaman itu akan berbuah manakala ia memiliki potensi untuk berbuah serta telah sampai pada waktunya berbuah.

Tugas seorang petani adalah menjaga agar tanaman itu tumbuh dengan sempurna, tidak terkena hama penyakit yang dapat menyebabkan tanaman tidak berkembang dan tidak tumbuh dengan sehat, yaitu dengan cara menyemai, menyiram, memberi pupuk dan memberi obat pembasmi hama.

Demikian juga halnya dengan seorang guru. Guru tidak dapat memaksa agar siswanya jadi "itu" atau jadi "ini". Siswa akan tumbuh dan berkembang menjadi seseorang sesuai dengan minat dan bakat yang dimilikinya. Tugas guru adalah menjaga, mengarahkan dan membimbing agar siswa tumbuh dan berkembang sesuai dengan potensi, minat dan bakatnya. Inilah makna peran sebagai pembimbing. Jadi, inti dari peran guru sebagai pembimbing adalah terletak pada kekuatan intensitas hubungan interpersonal antara guru dengan siswa yang dibimbingnya (Rukaiah Proklamasi Hasibuan, 2017:403).

Guru diberikan tugas oleh Negara untuk mendidik anak bangsa. Mereka sebagai pendidik kedua setelah orang tua. Namun guru mendapatkan tugas dari orang tua siswa untuk mengajarkan anak bangsa yang cerdas dan intelektual. Menurut (Rukaiah Proklamas Hasibuan, 2017:404), ada beberapa syarat bagi seorang guru dalam mengembangkan perilaku siswa serta tingkah laku diantaranya yaitu memiliki mental yang kuat, menguasai cara untuk menghindari pengaruh negatif terhadap siswa, terutama pada menyingkiran pengaruh negatif dari masa kanak-kanak yang mungkin ditularkan kepada siswa, secara tidak sadar dengan mengoptimalkan perannya sebagai pembimbing.

Menurut Tumiyen (2018:13), bimbingan dan konseling merupakan tugas yang harus diperlukan oleh pendidikan sebagai proses untuk membantu sekolah dalam menangani 
siswa untuk diberikan pemahaman diri atau pengarahan diri yang butuhkan secara maksimal. Bimbingan konseling tidak hanya diberikan kepada siswa yang bermasalah saja akan tetapi siswa yang ingin berbagi cerita keluh kesah untuk meminta solusi kepada guru BK.

Sesuai dengan penelitian
terdahulu kerjasama antar sekolah dengan orang tua bertujuan agar orang tua dapat mengetahui strategi sekolah baik guru maupun pihak sekolah lainnya untuk mendisiplinkan terhadap perlakuan siswa yang melanggar peraturan tata tertib sekolah. Anak akan mendapat perlakuan yang sama antara orang tua dan sekolah sehingga anak tidak akan lari dari proses pendidikan yang dilakukan.

Menurut (Rukaiah Proklamasi Hasibuan, 2017:404) terdapat beberapa hal yang harus diperhatikan terkait dengan penerapan kedisplinan yaitu Guru harus memiliki pemahaman tentang anak yang sedang dibimbingnya. Misalnya pemahaman tentang gaya dan kebiasaan belajar serta pemahaman tentang potensi dan bakat yang dimiliki anak, dan latar belakang kehidupannya. Pemahaman ini sangat penting, sebab akan menentukan teknik dan jenis bimbingan yang harus diberikan kepada mereka. Kemudian guru dapat memperlakukan siswa sebagai individu yang unik dan memberikan kesempatan kepada siswa untuk belajar sesuai dengan keunikan yang dimilikinya. Selanjutnya guru seyogyanya dapat menjalin hubungan yang akrab, penuh kehangatan dan saling percaya, termasuk di dalamnya berusaha menjaga kerahasiaan data siswa yang dibimbingnya, apabila data itu bersifat pribadi. Guru senantiasa memberikan kesempatan kepada siswanya untuk mengkonsultasikan berbagi kesulitan yang dihadapi siswanya, baik ketika sedang berada di kelas maupun di luar kelas. Terakhir guru sebaiknya dapat memahami prinsip-prinsup umum konseling dan menguasai teknik-tenik dasar konseling untuk kepentingan pembimbingan siswanya, khususnya ketika siswa mengalami kesulitankesulitan tertentu dalam belajarnya.

\section{KESIMPULAN}

Era digital telah memunculkan globalisasi pada setiap kehidupan manusia. Jaringan internet khususnya pada teknologi informasi komputer, setiap orang dengan mudah untuk memperoleh informasi dan media hiburan dengan cepat. Di era saat ini game online telah tersebar keseluruh penjuru dengan canggih teknologi informasi. Berkat kemajuan ilmu tekonologi Game online dapat berdampak positif pada siswa yaitu mudah berinteraksi dengan yang lain namun ada dampak negatif yang akan dialami orang-orang yang menggunakan kemajuan teknologi pada bidang internet mengalamai kecanduan sehingga melupakan dunia nyata yaitu terhadap perilaku siswa malas melakukan hal lain selain bermain game, boros apabila sedang bermain game dan berbohong pada orang tua demi bermain game online. Game online membuat para pemain senang menggunakannya karena memberikan sensasi dan menantang sehingga pemainnya lupa waktu karena dimainkan secara online dengan orang-orang yang berada jauh.

Oleh karena itu pendidik dan orang berperan memaparkan kepada 
Volume 3 No. 12020

siswa supaya belajar lagi untuk mengontrol diri dalam bermain game dengan banyak waktu yang telah dilewatkannya. Bagi orang tua siswa hendaknya memberi pemahaman pada anak bahwa bermain game boleh tetapi ada batasannya, yang kedua harus lebih ketat memantau kegiatan yang di lakukan anaknya. Bagi siswa hendaknya menyadari bagaimana waktu amat berharga sehingga harus dimanfaatkan sebaik mungkin. Pengurangan waktu bermain game hendaknya bisa dilakukan seperti mencari kegiatan kegiatan yang positif. Guru beperan memberikan motivasi, mendidik siswa untuk lebih semangat dalam belajar untuk mengurangi siswa dalam bermain game online. Pihak sekolah melakukan kerjasama dengan orang tua siswa untuk menindak lanjuti perlakuan siswa selama berada di lingkungan sekolah, serta menanamkan nilai-nilai karakter pada anak didik.

Berdasarkan hasil penelitian ini di harapkan kepada pihak Sekolah SMA Negeri 1 Bayang terutama pada keamanan sekolah utuk lebih memperhatikan aktivitas siswa selama berada disekolah. Peran guru dapat dimaksimalkan, tidak hanya memberikan motivasi dan nasehat kepada siswa SMA Negeri 1 Bayang agar tidak terjerumus ke hal negatif, khususnya pada guru pendidikan kewarganegaraan untuk menekankan aspek praktek teori. Para orang tua agar lebih peduli dengan aktivitas anaknya dengan berkmunikasi, memberikan perhatian, nasehat agar dapat lebih berhati-hati dalam bergaul dan berperilaku. Bagi siswa, permainan hanya sebagai sarana hiburan dan sekiranya tetap mengutamakan pembelajaran di sekolah. Bagi mahasiswa sebagai referensi dalam meningkatkan pengetahuan akan teknologi game online.

\section{DAFTAR PUSTAKA}

Andrew, Maurice. 2017. "Pengaruh Kecanduan Game online Siswa SMA Kelas $X$ Terhadap Kecerdasan Sosial Sekolah Kristen Swasta Di Makassar". Jurnal Jaffray

Amanda, Rika Agustina.2016. "Pengaruh Game online Terhadap Perubahan Perilaku Agresif Remaja Di Samarinda". Jurnal Ilmu Komunikasi

Tumiyen. 2018. "Program Bimbingan Dan Konseling Dalam Mengurangi Kecanduan Game online Oleh Siswa Kelas VIII SMA Melati Binjai Tahun Pelajaran 2017/2018". Jurnal AL-IRSYAD

Giandi,Ahmad Fajar. 2012. "Perilaku Komunikasi Pecandu Game online Dengan Menggunakan Game online". jurnal Universitas Padjadjaran

Fauziah,Eka Rusnani. 2013. “Pengaruh Game online Terhadap Perubahan Perilaku Anak Smp Negeri 1 Samboja". Jurnal lmu Komunikasi

Undang-Undang Nomor 20 Tahun 2003 Tentang "sistem pendidikan nasional"

Undang-undang Nomor 14 Tahun 2005 Tentang "Guru dan dosen"

Masya, Hardiyansyah dan Candra, Dian Adi. 2016. "Faktor-Faktor Yang Mempengaruhi Perilaku Gangguan Kecanduan Game online Pada Peserta Didik Kelas $X$ Di Madrasah Aliyah Al Furqon Prabumulih Tahun 
10 | dampak game online..

Pelajaran 2015/2016". Jurnal Bimbingan dan Konseling.

Syur'aini. 2015. "Penanaman Nilai Karakter Sebagai Upaya Mereduksi Dampak Negatif Era Digital". Jurnal Fip UNP

Sadulloh, Uyoh. 2015. "Pedagogik (ILMU MENDIDIK)".

Surakarta. Alfabeta.

Kartono, Kartini, 2008 : Pemimpin dan Kepemimpinan. Jakarta : PT. Raja Grafindo Persada.

Notoatmodjo, Soekidjo. 2010. “Ilmu Perilaku Kesehatan”. Jakarta. Rhineka Cipta

Syahran, Ridwan, 2015 :

"Ketergantungan Online Game Dan Penanganannya". Jurnal Psikologi Pendidikan \& Konseling

Hasibuan,Rukaiah Proklamasi. 2017 :

"Peran Guru Dalam

Pendidikan". Jurnal Ilmu Sosial

Universitas Negeri Medan

Anggarini, Yayu. "Dampak

Penggunaan Game online Terhadap Perilaku Remaja ( Studi Deskriptif Kuatitatif Pada Remaja Di Kelurahan asam Kumbang Meda)".

https://www.metrotvnews.com/play /N0BCGP6W-faktor-faktorpenyebab-kecanduan-gameonline

https:/ / lifestyle.kompas.com/r ead/2014/03/20/1642338/ Apa .Efeknya.jika.Orangtua.Jarang. Berkomunikasi.dengan.Anak. 